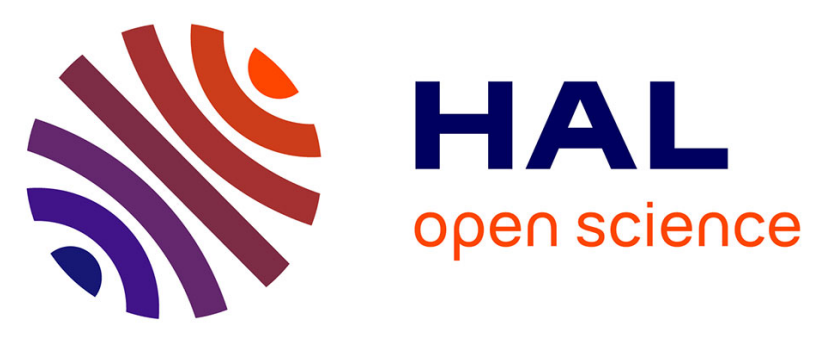

\title{
Advantages and limits of real-time PCR assay and PCR-restriction fragment length polymorphism for the identification of cutaneous Leishmania species in Tunisia.
}

Imène Ben Abda, Frédérique de Monbrison, Nadia Bousslimi, Karim Aoun, Aïda Bouratbine, Stéphane Picot

\section{To cite this version:}

Imène Ben Abda, Frédérique de Monbrison, Nadia Bousslimi, Karim Aoun, Aïda Bouratbine, et al.. Advantages and limits of real-time PCR assay and PCR-restriction fragment length polymorphism for the identification of cutaneous Leishmania species in Tunisia.. Transactions of The Royal Society of Tropical Medicine and Hygiene, 2011, 105 (1), pp.17-22. 10.1016/j.trstmh.2010.09.003 . pasteur00683984

\section{HAL Id: pasteur-00683984 \\ https://hal-riip.archives-ouvertes.fr/pasteur-00683984}

Submitted on 30 Mar 2012

HAL is a multi-disciplinary open access archive for the deposit and dissemination of scientific research documents, whether they are published or not. The documents may come from teaching and research institutions in France or abroad, or from public or private research centers.
L'archive ouverte pluridisciplinaire $\mathbf{H A L}$, est destinée au dépôt et à la diffusion de documents scientifiques de niveau recherche, publiés ou non, émanant des établissements d'enseignement et de recherche français ou étrangers, des laboratoires publics ou privés. 


\title{
Transactions of the Royal Society of Tropical Medicine and Hygiene
}

journal homepage: http://www.elsevier.com/locate/trstmh

\section{Advantages and limits of real-time PCR assay and PCR-restriction fragment length polymorphism for the identification of cutaneous Leishmania species in Tunisia}

\author{
Imène Ben Abda ${ }^{\mathrm{a}, \mathrm{b}}$, Frédérique de Monbrison ${ }^{\mathrm{b}, *}$, Nadia Bousslimi ${ }^{\mathrm{a}}$, Karim Aoun ${ }^{\mathrm{a}}$, \\ Aïda Bouratbine ${ }^{\mathrm{a}}$, Stéphane Picot ${ }^{\mathrm{b}}$ \\ a Research Laboratory of Emerging Parasitosis (LR 05 SP 03), Pasteur Institute of Tunis,13, Place Pasteur. BP 74-1002 Tunis, Tunisia \\ b Service Paludisme, Parasites du Sang et Mycologie Médicale, Hospices Civils de Lyon, 103 Grande Rue de la Croix Rousse, 69317 Lyon Cedex 04, France
}

\section{A R T I C L E I N F O}

\section{Article history:}

Received 13 April 2010

Received in revised form 1 September 2010

Accepted 1 September 2010

Available online $\mathrm{xxx}$

\section{Keywords:}

Cutaneous leishmania species

ITS1-PCR-RFLP

kDNA Real-time PCR

Tunisia

\begin{abstract}
A B S T R A C T
Cutaneous leishmaniasis (CL), a public health problem in Tunisia, is associated to three species: Leishmania (L.) infantum, L. major and L. killicki. Accurate and sensitive procedures for the diagnostic of Leishmania infection and for species identification are required to enable adequate treatment and appropriate control measures. Several PCR-methods are applied for the diagnosis and the identification of Leishmania parasites such as PCRrestriction fragment length polymorphism (PCR-RFLP), DNA sequencing, hybridization probes and real-time PCR (RT-PCR). In this study, PCR-RFLP and RT-PCR were performed on skin scrapings from 27 patients with confirmed CL by microscopic examination, in order to compare their usefulness and efficiency for identification of Leishmania species in routine diagnostic laboratories. Identification of Leishmania species was successfully achieved in $96.3 \%$ and $81.5 \%$ respectively. Agreement between using internal transcribed spacer 1 (ITS1)-PCR-RFLP and kDNA-RT-PCR assays was 70\% (19/27). Characterization problems using RT-PCR were mainly due to the difficulties in analyzing the melting temperatures.

ITS1-PCR-RFLP and kDNA-RT-PCR presented an interesting alternative to conventional methods for the identification of Leishmania parasites from clinical samples. Both PCR assays can be used in a routine diagnostic, however, further prospective studies including largest sampling, are required to determine their performances in a routine use.
\end{abstract}

(C) 2010 Royal Society of Tropical Medicine and Hygiene. Published by Elsevier Ltd. All rights reserved.

\section{Introduction}

Cutaneous Leishmaniasis (CL) is one of the most important resurgent parasitic vector-borne diseases endemic in many regions of the Old World: Central Asia, Middle East and the Mediterranean area. $^{1}$ It produces a broad spectrum of cutaneous lesions in humans, ranging from a small self-healing lesion to a disabling affliction. ${ }^{2}$ Relapses and treatment failures, especially when Leishmania tropica is involved, are major issues of the disease. ${ }^{3} \mathrm{CL}$ is

\footnotetext{
* Corresponding author. Tel.: +334 720015 17; fax: +33 472001521. E-mail address: demonbrison@sfr.fr (F. de Monbrison).
}

prevalent in many areas in Tunisia, related to three Leishmania species: (i) L. infantum associated to sporadic CL in the north of the country, (ii) L. major responsible for zoonotic CL in the centre and the south and (iii) L. killicki (syn. L. tropica MON-8) ${ }^{4}$, the causative agent of chronic $\mathrm{CL}$, in limited foci of the southeast and the centre of the country. ${ }^{5}$

In endemic areas, the presence of multiple Leishmania species with overlapping clinical features and geographical distribution requires the development of sensitive laboratory tests with Leishmania species identification in order to evaluate the prognosis of $\mathrm{CL}$ and to choose appropriate therapies. ${ }^{6,7}$ Species identification will also contribute to a better understanding of CL epidemiology. ${ }^{5}$

0035-9203/\$ - see front matter @ 2010 Royal Society of Tropical Medicine and Hygiene. Published by Elsevier Ltd. All rights reserved. doi: $10.1016 /$ j.trstmh.2010.09.003 
Currently, isoenzyme analysis is the gold standard technique for the characterisation and the classification of Leishmania parasites. ${ }^{4}$ However, this assay is culture dependent, time-consuming and arduous, requiring the examination of 15 different enzymatic profiles. For this reason, isoenzyme analysis is not available in a routine diagnostic laboratory. Moreover, difficulties in cultivating some species like L. infantum and the risk of contamination can hamper the identification of the parasite. . $^{8,9}$

In the past decade, several molecular methods were employed for the diagnostic and epidemiological studies on leishmaniasis. PCR technology was successfully applied for Leishmania diagnosis and identification of the causative species directly from clinical samples avoiding the need of cultivation. ${ }^{10-14}$ PCR-restriction fragment length polymorphism (RFLP) was widely used for species identification of Leishmania parasites. ${ }^{15-19}$ Real-time (RT) PCR, however, improved molecular diagnostics by adding simplicity and sensitivity. ${ }^{11,20-22}$

In the present work, we applied two PCR assays, a PCR-RFLP and subsequently RT-PCR to identify Leishmania species in 27 skin samples collected from Tunisian patients with confirmed CL. Our aim was to evaluate their advantages and limits in the identification of Leishmania species in a routine diagnostic laboratory-use.

\section{Materials and methods}

\subsection{Samples}

\subsubsection{Clinical specimens}

Samples of dermal scrapings were collected from 27 patients with CL referred to the Parasitology Laboratory in the Pasteur Institute of Tunis (PIT), Tunisia, for parasite diagnosis or during epidemiologic investigations conducted in Tunisia from 2005 to 2009. All patients or their legal guardians enrolled in the study provided free and verbal consent.

All patients were Tunisian nationals originated from 10 governorates of Tunisia: three patients from the north, 3 from the centre and 21 from the south. After cleaning with alcohol, scrapings were obtained from the active edge of the lesion using sterile lancets. The diagnosis of $\mathrm{CL}$ was confirmed in all patients by direct examination of Leishmania amastigotes in Giemsa-stained skin slit smears. Leishmania promastigotes were isolated in 14 out of 21 cultures, performed in Novy-MacNeal-Nicolle medium. ${ }^{23}$ The 14 isolates were typed by isoenzyme analysis, carried out in the Reference Center for Leishmania typing, Pasteur Institute of Algiers (Algeria).

All samples were subjected to a DNA extraction and submitted to DNA amplification for Leishmania species identification. PCR-RFLP was performed in the parasitology laboratory of PIT and RT-PCR in Service Paludisme, Parasites du Sang et Mycologie Médicale, Lyon, France.

\subsection{Leishmania reference strains}

Six reference strains were used as positive controls: L. infantum MHOM/TN/2005/LC11, L. major MHOM/TN/ 2003/LCT4, L. killicki MHOM/TN/2003/LCK in PCR-RFLP and
L. infantum MHOM/TN/80/IPT1, L. major MHOM/SU/73/5ASKH, L. tropica MHOM/SU/74/SAF -K27 in RT-PCR.

L. infantum MHOM/TN/80/IPT1, L. major MHOM/SU/ 73/5-ASKH and L. tropica MHOM/SU/74/SAF-K27 were kindly provided by M. Gramiccia, Istituto Superiore di Sanita in Roma, Italy.

L. infantum MHOM/TN/2005/LC11, L. major MHOM/TN/ 2003/LCT4 and L. killicki MHOM/TN/2003/LCK were gifted from Pasteur Institute of Algiers (Algeria).

The six reference strains were isoenzyme typed using the technique described by Rioux et al. ${ }^{4}$

Reference strains were cultivated at $25^{\circ} \mathrm{C}$ in RPMI medium supplemented with $15 \%$ foetal calf serum and penicillin. Parasites were harvested at a density of $10^{4}$ parasites $/ \mathrm{ml}$. They were washed twice with PBS buffer, pelleted with centrifugation $(5900 \times g$ for $3 \mathrm{~min})$ and stored at $-20^{\circ} \mathrm{C}$ until DNA extraction.

\section{Molecular diagnosis}

\subsection{DNA extraction}

\subsubsection{Clinical samples}

DNA extraction was performed on scrapped products in all patients in PIT using QiAamp DNA Blood Mini Kit (Qiagen ${ }^{\circledR}$, Hilden, Germany) according to the manufacturer's instructions. DNA was eluted from the column with $100 \mu \mathrm{l}$ of TE Buffer. Samples were kept at $-20^{\circ} \mathrm{C}$ until used.

\subsubsection{Leishmania reference strains}

DNA was isolated from promastigote forms using QiAamp DNA mini kit following the manufacturer's instructions, with minor modifications. The incubation time with proteinase $\mathrm{K}$ at $56^{\circ} \mathrm{C}$ was increased to $1 \mathrm{~h}$ and DNA was eluted from the column with $50 \mu$ l of PCR grade $\mathrm{H} 20$.

\subsection{Molecular analysis}

\subsubsection{PCR-RFLP}

This assay was carried out first in PIT, as previously described by Schönian et al. ${ }^{15}$ LITSR $\left(5^{\prime}\right.$-CTGGATCATTTTCCGATG-3') and L5.8S (5'TGATACCACTTATCGCACTTA-3') primers were used for amplification of ribosomal internal transcribed spacer (ITS) 1 region. Amplification reactions were performed in a $50 \mu \mathrm{l}$ volume. The extracted DNA $(5 \mu \mathrm{l})$ was added to $45 \mu \mathrm{l}$ of reaction mixture containing $50 \mathrm{mM}$ of $\mathrm{MgCl}$, $25 \mu \mathrm{M}$ of each primer (LITSR and L5,8S),10 mM dNTP's and $5 \mathrm{U}$ Taq polymerase. Conditions for cycling were $94^{\circ} \mathrm{C}$ for $4 \mathrm{~min}$, followed by 36 cycles of $95^{\circ} \mathrm{C}$ for $40 \mathrm{~s}, 53^{\circ} \mathrm{C}$ for $30 \mathrm{~s}$, $72{ }^{\circ} \mathrm{C}$ for $60 \mathrm{~s}$ and $72{ }^{\circ} \mathrm{C}$ for $6 \mathrm{~min}$. Leishmania DNA from three reference strains and water were used as positive and negative controls in each PCR experiment.

After the amplification, PCR product was analysed on $2 \%$ agarose gel by electrophoresis and visualized under ultraviolet light after staining in ethidium bromide. The reference strains gave a PCR product lying from 300-350 base pairs (bp). Secondly, amplicons were subjected to a digestion with the endonuclease HaeIII (Hybaid GmbH, Heidelberg, Germany) at $37^{\circ} \mathrm{C}$ for 1 hour following the manufacturer's 
instructions. Fragment length was analyzed to characterize Leishmania species, after agarose electrophoresis (2\%) and ethidium bromide staining. ${ }^{15}$ Band patterns obtained after digestion, were compared to the patterns obtained with the reference strains. The digestion with the restriction enzyme HaeIII revealed three bands for $L$. infantum MHOM/TN/2005/LC11 (200, 100, and $50 \mathrm{bp}$ ), two bands for L. tropica/killicki MHOM/TN/2003/LCK (220 and 50 bp), and two for L. major MHOM/TN/2003/LCT4 (220 and 127 bp).

\subsubsection{Real-time $P C R$}

The extracted DNA from the 27 samples was subjected to RT-PCR amplification, as previously described. ${ }^{19,20}$ Primers JW13 and JW14, designed on the conserved region of Leishmania kDNA minicircle, were used for the amplification of $L$. infantum, $L$. major and $L$. tropica. ${ }^{21}$ RT-PCR technology was performed by hot-start PCR using LightCycler FastStart DNA Master SYBR Green I Kit (Roche Diagnostics $^{\circledR}$, Meylan, France) in a LightCycler ${ }^{\mathrm{TM}}$ (Roche Diagnostics ${ }^{\circledR}$ ).

The extracted DNA ( $5 \mu \mathrm{l})$ was added to $15 \mu \mathrm{l}$ of reaction mixture containing $4 \mathrm{mM}$ of $\mathrm{MgCl} 2,0.5 \mu \mathrm{M}$ of each primer (JW13 and JW14), $2 \mu \mathrm{l}$ of LightCycler FastStart DNA Master SybrGreen I buffer (Roche Diagnostics ${ }^{\circledR}$ ). Conditions for cycling were similar as previously mentioned, ${ }^{21}$ and PCR product identity was confirmed with melting curve analysis.

To ensure the reproducibility of the assay, three positive controls (DNA from L. major, L. infantum and L. tropica reference strains), were included in each run. A negative control (uninfected sample), and a contamination control (water) were also added.

\section{Results}

\subsection{ITS1-PCR-RFLP}

DNA from 26 out of the 27 examined samples (96.3\%) was amplified and presented restriction band patterns correlated to reference strains. L. major was identified in 15 samples, L. tropica/killicki in six samples and L. infantum in five. PCR-RFLP identification correlated with that of isoenzyme analysis and DNA sequencing performed respectively in 13 cases (eight characterized as L. major, three as L. killicki and two as L. infantum) and three cases (two as L. killicki and one as L. infantum).

\section{2. $k D N A-R T-P C R$}

The post-amplification melting temperature (Tm), related to the sequence of the PCR products, allows the discrimination between the three positive controls included in each run. $L$. major, $L$. infantum and $L$. tropica could be easily differentiated by their Tm values. Their Tms were, respectively, $87 \pm 0.5^{\circ} \mathrm{C}$ for $L$. major (MHOM/ SU/73/5ASKH), $89.3 \pm 0.3^{\circ} \mathrm{C}$ for $L$. infantum (MHOM/TN/80/IPT) and $88.5 \pm 0.2{ }^{\circ} \mathrm{C}$ for $L$. tropica (MHOM/SU/74/K27). The variability between different runs did not exceed $0.57 \%$. The identification of Leishmania species from clinical samples was realised by comparison to the Tm values of the positive controls.
The specificity of the RT-PCR was confirmed by the lack of Tm with water control and DNA extracted from human healthy skin tissue (data not shown). Eighteen out of the 27 examined samples had Tms conforming to that of reference strains; 17 corresponded to $L$. major and one to $L$. tropica/ killicki (Table 1). Four samples, presenting a Tm at $84.3 \pm 0.3^{\circ} \mathrm{C}$ different from reference strains Tm values, were associated to $L$. infantum as previously described ${ }^{20}$ (Table 1). One out of those four samples was tested using isoenzyme analysis and/or DNA sequencing and confirmed as $L$. infantum species (Table 1 ). Overall, the identification of Leishmania species by kDNA-RT-PCR was achieved in 22 out of the 27 examined samples (81.5\%). Two of the five non-identified samples were undetermined exhibiting an overlapping Tm with that of reference strains, and DNA amplification failed in three cases.

\subsection{ITS1-PCR-RFLP and kDNA-RT-PCR}

The agreement between the ITS1-PCR-RFLP and the kDNA-RT-PCR for the identification of Leishmania species was 70\% (19/27): 14 samples corresponding to L. major, one to L. tropica/ killicki and four to L. infantum (Table 1). Identification correlated with isoenzyme or molecular typing when performed (Table 1). Using ITS1-PCR-RFLP, identification failed in one sample, corresponding to L. major by kDNA-RT-PCR and isoenzyme analysis (Table 1 ). Using kDNA-RT-PCR, identification failed in five samples. The three non-amplified samples were identified by PCR-RFLP and isoenzyme typing as L. major, L. tropica/killicki and $L$. infantum respectively.

The two undetermined samples were characterized as L. tropica killicki by ITS1-PCR-RFLP and confirmed by DNA sequencing and/or isoenzyme typing. Two samples were mis-identified, associated to L. major species by melting curve analysis but identified as L. killicki using isoenzyme analysis and/or DNA sequencing.

\section{Discussion}

With the advent of the PCR technology, several PCR based assays for species differentiation were developed. ${ }^{14-19}$ Many different PCR techniques and targets were used for this purpose, complicating the comparison between PCR identification results. Most molecular diagnostic methods applied for species identification were based on PCR-RFLP and RT-PCR. Several studies reported the efficiency of PCR-RFLP assay in identifying Leishmania species directly from clinical material. ${ }^{14-19}$ PCR assay is clearly less laborious than an isoenzyme analysis, the gold standard method. It avoids the need of parasite isolation, but this assay is less reproducible and provides complex band patterns not easily computerizable, exchangeable and comparable between different laboratories.

Several DNA targets were used for DNA amplification, such as the SSU rRNA gene ${ }^{24}$, the ITS regions ${ }^{15}$, the microsatellite DNA ${ }^{25}$ or extrachromosomal DNA, such as the repetitive kinetoplast DNA (kDNA) minicircles. ${ }^{11}$ Related to the sequence variation in the first part of the spacer, the ITS1-DNA target allows the identification of almost all medically relevant Leishmania parasites with the 
Table 1

ITS1-PCR-RFLP and kDNA-RT-PCR results for the identification of Leishmania species in 27 skin-lesions.

\begin{tabular}{|c|c|c|c|c|}
\hline Sample no. & PCR-RFLP result & RT-PCR result & Isoenzyme analysis ${ }^{\mathrm{a}}$ & DNA sequencinga \\
\hline $1-3,6,7,11,12,14$ & L. major & L. major & L. major $\mathrm{MON}-25$ & NA \\
\hline $4,5,8-10,13$ & L. major & L. major & NA & NA \\
\hline 15 & Non amplified & L. major & L. major MON-25 & NA \\
\hline 16 & L. major & non amplified ${ }^{\mathrm{b}}$ & NA & NA \\
\hline 17 & L. tropica & L. tropica & NA & NA \\
\hline 18 & L. tropica & L. major & L. killicki MON-8 & L. killicki \\
\hline 19 & L. tropica & L. major ${ }^{\mathrm{c}}$ & L. killicki MON-8 & NA \\
\hline 20 & L. tropica & undetermined $^{\mathrm{d}}$ & L. killicki MON-8 & L. killicki \\
\hline 21 & L. tropica & undetermined $^{\mathrm{d}}$ & NA & L. killicki \\
\hline 22 & L. tropica & non amplified ${ }^{\mathrm{b}}$ & NA & NA \\
\hline $23-25$ & L. infantum & L. infantum $\mathrm{e}^{\mathrm{e}}$ & NA & NA \\
\hline 26 & L. infantum & non amplified ${ }^{\mathrm{b}}$ & L. infantum $\mathrm{MON}-24$ & NA \\
\hline 27 & L. infantum & L. infantum $\mathrm{e}^{\mathrm{e}}$ & L. infantum MON-24 & L. infantum \\
\hline
\end{tabular}

ITS1: internal transcribed spacer 1; PCR: polymerase chain reaction; RFLP: restriction fragment length polymorphism; RT: real-time

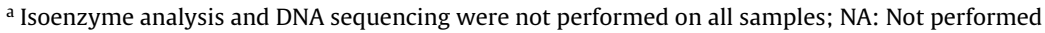

${ }^{\mathrm{b}}$ Non amplified samples: samples presenting no melting temperature (Tm) on RT-PCR

${ }^{\mathrm{c}}$ Mis-identified samples on RT-PCR (related to isoenzyme and/or DNA sequencing results)

d Undetermined samples: samples exhibiting an overlapping Tm with that of reference strains on RT-PCR

${ }^{\text {e }}$ samples presenting a Tm value at $83.4+/-0.3{ }^{\circ} \mathrm{C}$ on RT-PCR, associated to L. infantum species as previously described ${ }^{21}$ or after DNA sequencing and isoenzyme analysis.

The total of non amplified samples $\left({ }^{\mathrm{b}}\right)$ and undetermined samples $\left({ }^{\mathrm{d}}\right)$ corresponds to non-identified samples on RT-PCR.

use of only one restriction enzyme (HaeIII) for amplicon digestion. ${ }^{15}$ However, ITS1-PCR-RFLP is less sensitive compared to kDNA minicircles since the copy number of rDNA (less than 200) is lower than the copy number of kDNA minicircles (tens of thousands).

RT-PCR technology presents some advantages in terms of sensitivity and reliability, reduces the risk of DNA contamination and avoids the use of the carcinogen, ethidium bromide. Moreover, this assay offers accurate parasite detection, species identification with melting curve analysis of fluorescent $P C R$ products and specific DNA quantification. ${ }^{20-22}$ Related to its heterogeneity, in terms of size and sequence, the kinetoplast DNA (kDNA) is a good target for the detection and the identification of Leishmania parasites. ${ }^{26-28}$

According to the species previously reported in Tunisia and to their geographical distribution, the three endemic species, L. major, L. infantum and L. killicki were identified. $^{29,30}$ ITS1-PCR-RFLP and kDNA-RT-PCR allowed species identification in, respectively, 96.3\% (26/27) and $81.5 \%(22 / 27)$ of the 27 analyzed samples. RT-PCR succeeded to amplify and identify $L$. major in one sample missed by PCR-RFLP.

Although increased sensitivity of kDNA-RT-PCR was previously reported, ${ }^{11}$ this assay succeeded in our study to amplify and to identify only one sample missed by PCRRFLP. This could be related to the sample's conservation and the quite lengthy delay between the applications of both PCR assays. Since RT-PCR is an expensive method compared to RFLP-PCR, we suggest its use when the latter fails to amplify Leishmania DNA.

Nevertheless, the differentiation of the parasite species by PCR is not always obvious. The difficulty in separating $L$. major from $L$. tropica using PCR-RFLP has been previously reported $^{31}$ and the melting temperature analysis could sometimes be difficult in RT-PCR assay. In our study, in comparison to PCR-RFLP and/or isoenzyme analysis, kDNART-PCR failed in identifying the Tunisian L. tropica MON-8
(L. killicki) in five samples: two samples undetermined presenting a Tm overlapping with that of reference strains, two samples presenting a Tm corresponding to $L$. major and one was non amplified. A recent method based on High Resolution Melting Analysis allows the differentiation between $L$. tropica and $L$. major and should be an interesting alternative for a better species analysis. ${ }^{22}$

According to the results of DNA sequencing and a previous report, ${ }^{21}$ four samples, showing a Tm value at $84.3 \pm 0.3^{\circ} \mathrm{C}$ different from the references strains, were considered as $L$. infantum. The shifted and the overlapping Tm values may account for kinetoplast DNA polymorphism among Leishmania strains, which causes a variation of the amplified sequence and consequently of the corresponding melting temperature. Moreover, kDNA genotypes are dependent on the experimental conditions ${ }^{32}$ and standardization of kDNA RT PCR assay is needed to allow interlaboratory comparisons and maximize repeatability.

The genetic heterogeneity was reported in L. infantum kDNA, ${ }^{33}$ however, among $L$. tropica strains, it was only reported in Rdna and microsatellites. ${ }^{34,35}$ Additional investigations on $L$. tropica $\mathrm{kDNA}$ polymorphism will be required to clarify those findings. To overcome this difficulty, we suggest the use of more appropriate reference strains in each RT-PCR run. Finally, the absence of DNA amplification observed for three samples using RT-PCR may be due to deterioration of extracted DNA related to time, storage and carriage. In fact, samples were first tested in Tunisia using PCR-RFLP and sent many months after to France for RT-PCR identification. These conditions interfere with PCR output (amplification curve) and with reproducibility of results (melting curve differences) and consequently may explain the difference in DNA amplification between the two PCR assays. ${ }^{36}$ A prospective study could avoid this problem.

In conclusion, PCR-RFLP and RT-PCR represent an interesting alternative to isoenzyme analysis for the identification of CL species directly from clinical samples. To our knowledge, this is the first study describing the 
simultaneous application of molecular diagnostic tools for Leishmania species identification in patients with cutaneous leishmaniasis. Even if conducted on a small sampling, such study is required to evaluate the best assay performance for implementation in areas where the disease is endemic. However, a prospective study conducted on larger sampling would be necessary to assess the real efficiency and usefulness of ITS1-RFLP-PCR and kDNA-RTPCR for the identification of cutaneous Leishmania species.

Authors' contributions: $\mathrm{AB}, \mathrm{KA}$ and SP contributed to the design of the study. KA collected the samples. IBA carried out the RT-PCR. FDM and IBA analysed and interpreted the RT-PCR data. NB carried out the RFLP-PCR. AB and NB analysed and interpreted the RFLP-PCR data. FDM and IBA drafted the manuscript. All authors revised, read and approved the final manuscript. FDM is guarantor of the paper.

Acknowledgements: The authors are grateful to Marina Gramiccia (Instituto Superiore di Sanita in Roma, Italy) for providing the cell cultures of Leishmania reference strains and to Zoubeir Harrat (Pasteur Institute of Algiers, Algerie) for iso-enzyme typing. The authors thank Mohamed Raouene and Yahia Aloui (Direction Régionale de la santé publique de Tataouine, Tunisia) for enrollement of the patients and Cristophe Ravel (French National Reference Center for Leishmania, Montpellier, France) for the DNA sequencing of Leishmania samples.

\section{Funding: None}

Conflicts of interest: None declared.

Ethical approval: Ethical clearance was obtained from the Pasteur Institute of Tunis, Tunisia.

\section{References}

1. Dejeux P. Leishmaniasis: current situation and new perspectives. Comp Immunol Microbiol Infect Dis 2004;27:305.

2. Pearson RD, de Queiroz Sousa A. Clinical spectrum of leishmaniasis. Clin Infec Dis 1996;22:1-13.

3. Hadighi R, Mohebali M, Boucher P, Hajjaran H, Khamesipour A, Ouellette M. Unresponsiveness to glucantime treatment in Iranian cutaneous leishmaniasis due to drug-resistant Leishmania tropica parasites. PloS Med 2006;3:e162.

4. Rioux JA, Lanotte G, Serre E, Pratlong F, Bastien P, Perieres J. Taxonomy of Leishmania. Use of isoenzymes. Suggestions for new classification. Ann Parasitol Hum Comp 1990;65:111-25.

5. Aoun K, Amri F, Chouihi E, Haouas N, Bedoui K, Benikhlef R, et al. Epidemiology of Leishmania (L.) infantum, L. major and L. killicki in Tunisia: results and analysis of the identification of 226 human and canine isolates. Bull Soc Pathol Exot 2008;101:323-8.

6. Wortmann G, Hochberg L, Houng HH, Sweeney C, Zapor M, Aronson $\mathrm{N}$, et al. Rapid identification of Leishmania complexes by a real-time PCR assay. Am J Trop Med Hyg 2005;73:999-1004.

7. Jirkù M, Zemanová E, Al-Jawabreh A, Schönian G, Lukes J. Development of a direct species-specific PCR assay for differential diagnosis of Leishmania tropica. Diagn Microbiol Infect Dis 2006;55:75-9.

8. Belkaïd M, Harrat Z, Hemrioui B, Thellier M, Datry A, et Danis M. A propos d'un milieu simple pour l'isolement et la culture des leishmanies. Bull Soc Pathol Exo 1996;89:276-7.

9. Aoun K, Bouratbine A, Harrat Z, Guizani I, Mokni M, Bel Hadj Ali $\mathrm{S}$, et al. pidemiologic and parasitologic data concerning sporadic cutaneous leishmaniasis in northern Tunisia. Bull Soc Pathol Exot 2000;93:101-3.
10. Rodrigues EH, Felinto de Brito ME, Mendonça MG, Werkhäuser RP, Coutinho EM, Souza WV, et al. Evaluation of PCR for diagnosis of American cutaneous leishaniasis in an area of endemicity in northeastern Brazil. J Clin Microbiol 2002;40:3572-6.

11. Nicolas L, Milon G, Prina N. Rapid differentiation of Old World Leishmania species by LightCycler polymerase chain reaction and melting curve analysis. J Microbiol Methods 2002;51:295-9.

12. Oliveira FS, Pirmez C, Pires MQ Brazil RP, Pacheco RS. PCR-based diagnosis for detection of Leishmania in skin and blood of rodents from an endemic area of cutaneous and visceral leishmaniasis in Brazil. Vet Parasitol 2005;129:219-27.

13. Al-Jawabreh A, Schoenian G, Hamarsheh O, Presber W. Clinical diagnosis of cutaneous leishmaniasis: A comparison study between standardized graded direct microscopy and ITS-PCR of a Giemsastained smears. Acta Tropica 2006;99:55-61.

14. Toz SO, Nasereddin A, Ozbel Y, Ertabaklar H, Culha G, Sevil N, et al. Leishmaniasis in Turkey: molecular characterization of Leishmania from human and canine clinical samples. Trop Med Int Health 2009;14:1401-6.

15. Schönian G, Nasereddine A, Dinse N, Schweynoch C, Schallig HD, Presber W, et al. PCR diagnosis and characterization of Leishmania in local and imported clinical samples. Diagn Microbiol Infect Dis 2003;47:349-58.

16. Marfurt J, Nasereddin A, Niederwieser I, Jaffe CL, Beck HP, Felger I. Identification and differentiation of Leishmania species in clinical samples by PCR amplification of the miniexon sequence and subsequent restriction fragment length polymorphism analysis. J Clin Microbiol 2003;41:3147-53.

17. Gadisa E, Genetu A, Kuru T, Jirata D, Dagne K, Aseffa A, et al. Leishmania (Kinetoplastida): species typing with isoenzyme and PCR-RFLP from cutaneous leishmaniasis patients in Ethiopia. Exp Parasitol 2007;115:339-43.

18. Khatri ML, Di Muccio T, Gramiccia M. Cutaneous leishmaniasis in North-Western Yemen: a clinicoepidemiologic study and Leishmania species identification by polymerase chain reactionrestriction fragment length polymorphism analysis. J Am Acad Dermatol 2009;61:e15-21.

19. El Tai NO, El Fari M, Mauricio I, Miles MA, Oskam L, El Safi S, et al. Leishmania donovani: intraspecific polymorphisms of Sudanese isolates revealed by PCR based analyses and DNA sequencing. Exper Parasitol 2001;97:35-44.

20. Mihoubi I, de Monbrison F, Romeuf N, Moulahem T, Picot. Outsourced real-time PCR diagnosis of cutaneous leishmaniasis in the outbreak region of Constantine, Algeria. Algeria Med Trop 2006;66:3944.

21. Monbrison de F, Mihoubi I, Picot S. Real-time PCR assay for the identification of cutaneous Leishmania parasite species in Constantine region of Algeria. Acta Trop 2007;102:79-83.

22. Talmi-Frank D, Nasereddin A, Schnur LF, Schönian G, Töz SO, Jaffe CL, et al. Detection and identification of old world Leishmania by high resolution melt analysis. PloS Negl Trop Dis 2010;4:e581.

23. Chouihi E, Amri F, Bouslimi N, Siala E, Selmi K, Zallagua N, et al. Cultures on NNN medium for the diagnosis of leishmaniasis. Pathol Biol 2009;57:219-24.

24. Van Eys GJ, Schoone GJ, Kroon NC, Ebeling SB. Sequence analysis of small subunit ribosomal RNA genes and its use for detection and identification of Leishmania parasites. Mol Biochem Parasitol 1992;51:133-42.

25. Russell R, Iribar MP, Lambson B, Brewster S, Blackwell JM, Dye C, et al. Intra and inter-specific microsatellite variation in the Leishmania subgenus. Viannia Mol Biochem Parasitol 1999;103:71-7.

26. Brewster S, Barker DC. Analysis of minicircle classes in Leishmania (Viannia) species. Trans R Soc Trop Med Hyg 2002;96:S55-63.

27. Anders G, Eisenberger CL, Jonas F, Greenblatt CL. Distinguishing Leishmania tropica and Leishmania major in the Middle East using the polymerase chain reaction with kinetoplast DNA-specific primers. Trans R Soc Trop Med Hyg 2002;96:87-92.

28. Kumar R, Bumb RA, Ansari NA, Mehta RD, Salotra P. Cutaneous leishmaniasis caused by Leishmania tropica in Bikaner, India: parasite identification and characterization using molecular and immunologic tools. Am J Trop Med Hyg 2007;76:896-901.

29. Haouas N, Gorcii M, Chargui N, Aoun K, Bouratbine A, Messaadi Akrout $\mathrm{F}$, et al. Leishmaniasis in central and southern Tunisia: current geographical distribution of zymodemes. Parasite 2007;14:23946.

30. Bouratbine A, Aoun K, Ghrab J, Harrat Z, Ezzedini MS, Etlijani S. Spread of Leishmania killicki to Central and South-West Tunisia. Parasite 2005; 12:59-63.

31. Lemrani M, Hamdi S, Laamrani A, Hassar M. PCR detection of Leishmania in skin biopsies. J Infect Dev Ctries 2009;3:115-22. 
32. Bhattarai NR, Dujardin JC, Rijal S, De Doncker S, Boelaert M, Van der Auwera G. Development and evaluation of different PCR-based typing methods for discrimination of Leishmania donovani isolates from Nepal. Parasitology 2010;137:947-57.

33. Nasereddin A, Azmi K, Jaffe CL, Ereqat S, Amro A, Sawalhah G, et al Kinetoplast DNA heterogeneity among L. infantum strains in central Israel and Palastine. Vet Parasitol 2009;161:126-30.

34. Schönian G, Schnur L, El Fari M, Oskam L, Kolesnikov AA, SokolowskaKöhler W, et al. Genetic heterogeneity in the species Leishmania tropica revealed by different PCR-based methods. Trans $R$ Soc Trop Med Hyg 2001;95:217-24.

35. Schwenkenbecher JM, Wirth T, Schnur LF, Jaffe CL, Schallig H, Al Jawabreh A, et al. Microsatellite analysis reveals genetic structure of Leishmania tropica. Int J Parasitol 2006;36:237-46.

36. Bastien P, Procop GW, Reischl U. Quantitative real-time PCR is not more sensitive than "conventional" PCR. J Clin Microbiol 2008;46:1897-900. 